\title{
Response to the Growth and Production of Soybeans (Glycine max L) to the Time of Giving Irrigated Water to Maintaining Soil Moisture
}

\author{
Aminah ${ }^{1, *}$, Abdullah ${ }^{1}$, Nuraeni ${ }^{2}$, Marliana S Palad ${ }^{3}$
}

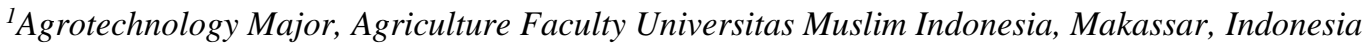 \\ Jalan Urip Sumihardjo Km. 5. 90231. Makassar Sulawesi Selatan, Indonesia \\ ${ }^{2}$ Agribusiness Major, Agriculture Faculty Universitas Muslim Indonesia, Makassar, Indonesia \\ ${ }^{3}$ Agrotechnology Major, Agriculture Faculty Universitas Muslim Indonesia Universitas Cokroaminoto, \\ Makassar, Indonesia \\ *Corresponding author. Email: aminah.muchdar@umi.ac.id
}

\begin{abstract}
This study aims to determine the response of growth and production of soybean (Glycine max L) on the time of offering irrigation water in maintaining soil moisture. Research in the form of an experiment using a randomized block design (RAK) consisted of four times of air giving, namely W1 = every 15 days of age, $\mathrm{W} 2=$ at full flowering, W3 = at the age of 15 days and at full flowering, W4 = every 10 days. The amount of air given is the same for each treatment, only the time to offer it is different, where the water requirement for soybean plants is obtained from previous research data where it was found that the water requirement for soybean crops was 6.1 liters per plant during its life cycle, the number of plants in one bed was 75 so that The total air needed in one bed until production is 457.5 liters $=458$ liters. W1 $=$ every 15 days of age ( 5 times to offer) $=458 / 5=91.6=92$ liters, W2 $=$ at full flowering ( 1 time to offer) $=458$ liters, $\mathrm{W} 3=$ at the age of 15 days and when it is full ( 2 times giving) $=458 / 2=229$ liters and W4 = every 10 days ( 8 times of giving) $458 / 8=57.25=57$ liters. The results of the investigation showed that offering every 10 days showed the highest water content (soil moisture) compared to other treatments, but the highest moisture content was not in line with the increase in the production component. The treatment of giving water every 15 days and offering water while giving full warning of the best effect on almost all production components, namely the number of seeds planted (161.99), weight 100 seeds (27.5 grams), number of pods (80.67), the weight of seeds per plant (23.83 grams), and production per hectare (3.2 tons/hectare). This shows that the time to offer water at the age of 15 days and when it is in full bloom with the amount of giving 229 liters of water each time (twice) is able to meet the optimal water needs of the growth phase and development even to the production of soybean plants.
\end{abstract}

Keywords: Soybean, time of providing water, Soil Moisture

\section{INTRODUCTION}

Soybean, as a food ingredient that is very popular in Indonesia, ranks third after rice and corn because it has a high enough protein content. Soybean nowadays are not only used as a source of protein but also as a functional food that can prevent degenerative diseases such as coronary heart disease and hypertension because they contain isoflavones which are antioxidants. [1].
However, domestic production is not able to keep up with national needs, so it must be pursued by import. One way to increase soybean production is to increase the harvested area which can be achieved by extending it to dry land areas which are very large in Indonesia, this can be achieved if water management on the land can be implemented optimally. Given that optimal plant growth and yields can be achieved if water as the most important factor in plant growth can be available in sufficient 
quantities according to plant needs. One of the solutions offered is knowing the proper water management system to meet the water needs of soybean plants, especially on dry land, to support food security.

Soybean is an important crop that requires sufficient water availability during its growth process to achieve high yields [2]. However, drought stress does not only cause crop damage. After a certain degree of drought stress, and for a short time after rehydration, soybean plants may exhibit compensated positive physicobiochemical growth or overcompensation in terms of metabolism and growth and development to compensate for the damage and losses caused during drought stress. [3][4][5].

The main consequences of changing water resources for agricultural production include: (i) increased water demand in all areas due to increased evapotranspiration of crops in the face of rising temperatures; (ii) increasing water shortages, especially in summer months, increasing water requirements for irrigation (iii) decreasing water quality due to higher water temperatures and lower runoff rates in some areas [6].

Agricultural development on dry land for food crops needs to be encouraged by various technological innovations, given its large potential so that it is potential enough to support efforts to strengthen food security. Developing lowland dryland agriculture for food today and in the future is a strategic choice in facing the challenge of increasing food production to support national food security programs. [7]. Seeing the potential of dry land above, there are many opportunities to examine more deeply about the best time to provide the best water to soybean plants on dry land (rainfed), considering the main obstacle faced in dry land management is limited water due to very low rainfall, so that The solution offered in this research is the proper management of water delivery time, especially on dry or rainfed land. This is in line with research [8] which states that regulating the frequency of water supply and managing water availability can increase soybean productivity

\section{RESEARCH METHOD}

This research was conducted in the field, namely on dry land in Jeneponto Regency from April 2020 to September 2020. The experiment used a randomized block design, which consisted of four treatments for the time of giving water and field capacity as a comparison and was repeated three times. The treatment of irrigation water delivery time is:

$\mathrm{W} 1$ = Every 15 days old

$\mathrm{W} 2=$ When in full bloom

$\mathrm{W} 3=15$ days of age and at full flowering and

W4 = Irrigation every 10 days.
The amount of water given is the same for each treatment, only the time of giving is different, where the water requirement for soybean plants is obtained from previous research data (in the green house) where it was found that the water requirement for soybean crops was 6.1 liters during its life cycle, the number of plants in one 75 beds so that the total water needed in one bed until production is 457.5 liters $=458$ liters. $\mathrm{W} 1=$ every 15 days ( 5 times of giving) $=458 / 5=91.6=92$ liters, $\mathrm{W} 2=$ at full flowering $(1$ time $)=458$ liters, W3 = at the age of 15 days and at full flowering ( 2 times giving $)=458 / 2=229$ liters and W4 = every 10 days ( 8 times of giving) 458/8 $=57.25=57$ liters.

In the field, isolation was made between treatments at a minimum distance of 5 meters to avoid water seepage from other treatment plots. In each plot, a sluice gate was built with a water gauge to calculate the amount of water entering. The plot size was $4 \mathrm{~m} \times 6 \mathrm{~m}$, and the water channel was made according to the width of the plot (4 $\mathrm{m})$ as well as the boundary of the treatment plot. The water channel is made $30 \mathrm{~cm}$ deep and $25 \mathrm{~cm}$ wide. The provision of water in the plot is limited to the time that the water is given until it passes the ground surface, then the plot is closed so that it does not flow out. At the same time, planting was given basic fertilizer at a dose of 50 $\mathrm{kg}$ Urea $+75 \mathrm{~kg} \mathrm{SP} 36+75 \mathrm{~kg} \mathrm{KCl} / \mathrm{ha}$

\subsection{Observation of plant growth}

Includes plant height, number of leaves, leaf greenness, root length, root dry weight and plant dry weight, c. Observation of soil water content to see how much time the water was given is able to maintain the optimal soil moisture level for soybean plants.

\subsection{Observation of crop production}

Includes number of pods, number of seeds in pods, weight of 100 seeds, weight of seeds per plant, production per plot and production per hectare. The data were analyzed using Variance Analysis and continued with the Middle-Value Test, namely BNT 5\%.1.1.1.

\section{RESULTS AND DISCUSSION}

From Table 2 and Table 3 below, it can be seen that the treatment of water application time has a significant effect on all observed components, both growth and production components.

In Table 1, it can be seen that the provision of water every 10 days has a groundwater content in the vicinity and even slightly exceeds the groundwater content in the field capacity conditions of 43.49 to $46.97 \%$, even though the amount of water given is the same as a whole, but this is the time of giving it which distinguishes the results, where by giving every 10 days and 15 days, almost every 
phase of plant growth and development gets sufficient water.

Table 1. Effect of water irigation providing time on soil moisture content

\begin{tabular}{lccc}
\hline \multirow{2}{*}{ Treatment } & \multicolumn{3}{c}{ Soil Water Content } \\
\cline { 2 - 4 } & I & II & III \\
\hline Field Capacity. & 45,55 & 43,49 & 46,97 \\
Water providing each 15 & 39,96 & 42,53 & 41,95 \\
days (W1) & & & \\
Water Providing on full & 29,45 & 27,99 & 25,43 \\
bloom (W2) & & & \\
Water Providing in 15 days & & & \\
and on & 36,67 & 36,43 & 32,99 \\
full bloom (W3) & 46,38 & 45,29 & 42,87 \\
Water Providing each 10 & & & \\
days (W4) & & & \\
\end{tabular}

*) soil moisture content is maintained field capacity
Alfisol-type soil that is used as a growing medium has a light texture so that at the time of administration every 10 days or every 15 days the moisture content of the soil is around field capacity, even above field capacity. This is in accordance with the opinion [9], which states that the important factors underlying water management are the properties of plants to water needs, the amount of water supplied, the time of water and how to irrigation and the characteristics of the soil in storing water.

Another point of concern in water management is that climate change will cause many of the economic and social challenges to be faced by water management in agriculture [10][11][12][13]. Although the results are mixed and sometimes contradictory, common elements is that one of the main impacts of climate change is a reduction in the availability of water for irrigation purposes in each region [11].

The results of observations on plant height, harvest age, leaf area, root length and plant dry weight are presented in Table 2.

Table 2. The effect of water application time on plant height, crop harvest age, harvest age, leaf greenness, root length and plant dry weight

\begin{tabular}{|c|c|c|c|c|c|}
\hline Treatment & $\begin{array}{c}\text { Plant } \\
\text { Height }(\mathrm{cm})\end{array}$ & $\begin{array}{l}\text { Greenish } \\
\text { leaves }\end{array}$ & $\begin{array}{l}\text { Harvest } \\
\text { Age } \\
\text { (Day) }\end{array}$ & $\begin{array}{l}\text { Root } \\
\text { Length } \\
(\mathrm{cm})\end{array}$ & $\begin{array}{c}\text { Plant Dry } \\
\text { Weight } \\
\text { (gr) }\end{array}$ \\
\hline Field Capacity. & 55,11 & 31,67 & 84,77 & 21,93 & 35,20 \\
\hline Water providing each 15 days (W1) & $63,22 \mathrm{a}$ & $31,98 b$ & $89,18 \mathrm{a}$ & $18,70 \mathrm{~b}$ & $43,10 \mathrm{c}$ \\
\hline Water Providing on full bloom (W2) & $49,78 b$ & $26,32 d$ & $89,07 \mathrm{a}$ & $25,43 a$ & $30,03 \mathrm{~d}$ \\
\hline $\begin{array}{l}\text { Water Providing in } 15 \text { days and on full } \\
\text { bloom (W3) }\end{array}$ & $64,56 \mathrm{a}$ & $29,95 \mathrm{c}$ & $86,56 b$ & $19,40 \mathrm{~b}$ & $83,03 \mathrm{a}$ \\
\hline Water Providing each 10 days (W4) & $62,45 \mathrm{a}$ & $42,57 \mathrm{a}$ & $76,44 \mathrm{c}$ & $16,00 \mathrm{c}$ & $55,17 \mathrm{~b}$ \\
\hline HSD 5\% & 2,78 & 1,58 & 2,11 & 1,81 & 2,26 \\
\hline
\end{tabular}

Plant growth, which is characterized by plant height, is influenced by the time of giving water, which can be seen from the results of research giving water twice at the age of 15 days and when in full flowering shows the highest plant growth, this shows that the provision of water is given in sufficient quantities for the vegetative phase namely the age of 15 days and the generative phase at full flowering (229 liters per time) are able to meet the optimal needs in both phases so that it affects the growth of plant height, while the time of giving water during full flowering (W2) is only given once in the amount of 458 liters is considered unable to maintain soil moisture content until it enters the generative phase so that plant growth experiences obstacles which are characterized by shorter growing plants. Compared to other times of giving water, it is suspected that in this condition, the plants experience a significant water stress stage that causes them to suffer. show the decrease in growth variables in stressed plants. [14] explained that this phenomenon is a result of water stress, so that other plant physiological activities are also hampered.

In general, plant height is getting lower at the interval of giving water which is very decreasing, which is only one time (W2), which is $49.78 \mathrm{~cm}$, caused by insufficient water availability, which causes the availability of nutrients and nutrient solubility in the soil to decrease. Thus, nutrient transport to plant tissue will also be lower. This is consistent with a study conducted by [15] that soybean plants grown in plastic houses with reduced water supply intervals caused a $9.2 \%$ reduction in plant height. In addition, a study conducted [16] showed that soybean, which was given drought stress by reducing the 
intensity of water supply in the generative phase, also caused a reduction in plant height.

The timing of irrigation water had a very significant effect on leaf greenness, which is an indicator of leaf chlorophyll content (Table 2). Where the provision of water twice, namely at the age of 15 days and at full flowering with the amount of water 229 liters each time it is given, has the highest leaf greenness compared to other times of giving water, namely when in full flowering (giving water once is 458 liters), for each age 15 days (giving water five times, namely 92 liters per given) and giving water every 10 days. (giving water 8 times, which is 57 liters each time), this is because at the age of 15 days is the vegetative period and flowering is the beginning of the generative period where sufficient water is needed (229 liters each time), although only twice is given, the amount is more than the time of giving water every 15 days (five times giving water / W1) and every 10 days (giving water eight times / W4).

Leaf greenness correlates with leaf chlorophyll content, the greener a leaf is, the more chlorophyll content and the higher the ability to photosynthesize, it can also be a sensitive tool to identify genotypic variations in estimating the rate of photosynthesis and can serve as selection criteria in plant breeding programs [6]. Chlorophyll is a determining element of plant photosynthetic ability, which is mostly found in plant leaves. Leaf chlorophyll levels are closely related to leaf greenness. Chlorophyll is a pigment that has a function in the photosynthetic process of plants. The higher the leaf chlorophyll content, the higher the ability to photosynthesize. [17] said that in the process of photosynthesis, plant chlorophyll is a complex molecule that plays a role in capturing sunlight energy which is a process of energy and electron transfer.

Table 1, shows the effect of irrigation water delivery time every 10 days giving the fastest effect on harvest time, which is 76 days, this means that the water given every 10 days is able to meet the water needs of each phase from the growth and production stages to accelerating the harvest period, it is just not correlated positively with production.

The longest root length was shown by the treatment of water when in full flowering, where this treatment showed that the soil was deprived of water due to water supply at once and only once so that the roots would extend themselves (root interception) to find further space to get water, this is in line with the study [18] which found that soybean plants that were stressed by water tended to extend themselves compared to plants that received normal irrigation.

The biggest accumulation of biomass also occurred at 15 days of water administration and at full flowering, namely 83.03 grams. (Table 2). And it turns out that this also has an impact on increasing production components such as the number of pods, weight of seeds planted for production (Table 3 ).

The results of observations on the number of seeds per plant, the weight of 100 seeds, number of pods, the weight of seeds per plant and production per hectare are presented in Table 3.

Table 3. The effect of water application time on the number of seeds per plant, the weight of 100 seeds, the number of pods, the weight of seeds per plant and production per hectare.

\begin{tabular}{lccccc}
\hline \multicolumn{1}{c}{ Treatment } & $\begin{array}{c}\text { Number of } \\
\text { seeds per } \\
\text { plant }\end{array}$ & $\begin{array}{c}\text { weight } \\
100 \\
\text { seed } \\
\text { (gram) }\end{array}$ & $\begin{array}{c}\text { Number of } \\
\text { pods }\end{array}$ & $\begin{array}{c}\text { weight of } \\
\text { seeds per } \\
\text { plant } \\
\text { (gram) }\end{array}$ & $\begin{array}{c}\text { production } \\
\text { per hectare } \\
\text { (ton) }\end{array}$ \\
\hline Field Capacity. & 94,81 & 18,83 & 31,33 & 13,27 & 1,66 \\
Water Providing each 15 days (W1) & $89,87 \mathrm{c}$ & $22,46 \mathrm{~b}$ & $40,33 \mathrm{c}$ & $19,23 \mathrm{~b}$ & $2,41 \mathrm{~b}$ \\
Water providing on full bloom (W2) & $76,10 \mathrm{~d}$ & $16,36 \mathrm{~d}$ & $31,67 \mathrm{~d}$ & $12,17 \mathrm{~d}$ & $1,52 \mathrm{~d}$ \\
Water providing in 15 days and full bloom & $161,99 \mathrm{a}$ & $27,50 \mathrm{a}$ & $80,67 \mathrm{a}$ & $23,83 \mathrm{a}$ & $3,21 \mathrm{a}$ \\
(W3) & $95,05 \mathrm{~b}$ & $21,10 \mathrm{c}$ & $66,33 \mathrm{~b}$ & $18,37 \mathrm{c}$ & $2,30 \mathrm{c}$ \\
Water providing each 10 days (W4) & 1,72 & 0,60 & 4,16 & 0,72 & 0,15 \\
\hline BNT 5\% & & & &
\end{tabular}

Water treatment at the age of 15 days and at full flowering showed a very real response to all production components (number of seeds per plant, the weight of 100 seeds, number of pods, the weight of seeds per plant and production per hectare). These results suggest that the optimal time of giving water in both phases, the vegetative phase (15 days) and the generative phase (when flowering) gives the best results compared to other treatments, although only two times the amount of water given (229 liters per giving) is considered able to maintain soil moisture content until production. Meanwhile, the lowest production was obtained at the time of giving water once, that is, during full flowering, where the amount of water given at once is 458 liters, but 
it is considered unable to maintain soil moisture content until production, this may be due to each phase of plant growth required a different amount of water. These results suggest that the time to give water at that time (age 15 days and when in full flowering) is an important factor that needs to be considered to increase water use efficiency and increase the yield of soybean seeds, especially those grown on dry alpha soil.

The availability of sufficient water during plant growth, especially the vegetative and reproductive phases, greatly determines the yield of soybeans. The amount required is different for each growth phase. Water consumption for soybean plants is highly dependent on climate, soil type, soil management and duration of plant growth, thus the water requirements for each agroecosystem area are different. Although soybeans as secondary crops do not require much water, during the early stages of growth, flowering and filling of pods, water availability is needed. If you experience drought at that stage, soybean productivity can decrease by $40-65 \%$ [19].

The results of the study [20] found that soybeans given water stress of $150 \mathrm{~mm} / \mathrm{season}$ (below normal requirements) showed a very significant difference with soybeans that received $300 \mathrm{~mm}$ of water/season (normal needs), namely a very significant decrease in both the growth components plants as well as the production components.

Agricultural development on dry land for food crops needs to be encouraged by various technological innovations, given its large potential so that it is potential enough to support efforts to strengthen food security. Developing lowland dryland agriculture for food now and in the future is a strategic choice in facing the challenge of increasing food production to support national food security programs.

\section{CONCLUSION}

The conclusion from this research is that the time of giving water at 15 days and at full flowering is a very efficient time that is able to maintain soil moisture content. This is evident from that time showing the best effect on almost all production components, namely the number of seeds planted (161.99), weight of 100 seeds (27.5 grams), number of pods (80.67), weight of seeds per plant (23.83 grams), and production per hectare (3.2 tons / hectare). This shows that the time of giving water at the age of 15 days and at full flowering with the amount of water given 229 liters for each time (twice) is able to meet the optimal water needs for each phase of growth and development even down to soybean production.

\section{ACKNOWLEDGMENTS}

The authors would like to thank the Ministry of Research Technology and Higher Education of Indonesia (Grant no. 0541.a/B.07/UMI/II/2019) for funding this research.

\section{REFERENCES}

[1] Badan Penelitian dan Pengembangan Pertanian. Petunjuk Teknis Budidaya Kedelai. Kementerian Pertanian. 2008

[2] J. Buezo, A. Sanz-Saez, J.F. Moran, D. Soba, I. Aranjuelo, R. Esteban, "Drought tolerance response of high-yielding soybean varieties to mild drought: physiological and photochemical adjustments". Physiol. Plantarum 166 (1) (2019) 88-104.

[3] H. Liu, W. Zheng, F. Zheng, L. Wang, "Influence of rewatering on compensatory effect of maize seedling roots with diluted seawater irrigation". Trans. Chinese Soc. Agric. Eng. 28 (3) (2012) 101106.

[4] S. Hao, X. Guo, W. Wang, "Aftereffects of water stress on corn growth at different stages". Trans. Chinese Soc. Agric. Eng. 26 (7) (2010) 71-75.

[5] H. Y. Xue, Y.J. Zhang, L.T. Liu, H.C. Sun, C.D. $\mathrm{Li}$, "Responses of spectral reflectance, photosynthesis and chlorophyll fluorescence in cotton during drought stress and rewatering". Scientia Agricultura Sinica, 46 (1) (2013) 23862393.

[6] A. Iglesias, L. Garrote, “Adaptation strategies for agricultural water management under climate change in Europe". Agriculture Water Management 155 (2015) 113-124.

[7] Badan Pusat Statistik (BPS), Produksi Tanaman Pangan di Indonesia, 2018

[8] M. A. Muhumed, S. Jusop, C.T.B. P.E.M. Wahab, Q.A. Panhwar. "Effects of drip irrigation frequency, fertilizer sources and their interaction on the dry matter and yield components of sweet corn”. J. Crop. Sci. 8 (2014) 223-231.

[9] E.H.F.M. da Silva, A. O. Gonçalves, R.A. Pereira, I.M. Fattori Jr, L.R. Sobenko, F. R. Marin, "Soybean irrigation requirements canopyatmosphere coupling in Southern Brazil", Agricultural Water management 218 (2019) 1-7. https://doi.org/10.1016/j.agwat.2019.03.003

[10] C. Rosenzweig, K. Strzepek, D. Major, A. Iglesias, D. Yates, A. Holt, D. Hillel, "Water availability for agriculture under climate change: five international studies". Glob. Environ. Change 14 (2004) 345360. 
[11] EEA, Water Resources in Europe in the Context of Vulnerability. EEA 2012 State of Water Assessment. EEA Report No 11/2012. European Environment Agency, 2012

[12] A. Iglesias, S. Quiroga, A. Diz, "Looking into the future of agriculture in a changingclimate". Eur. Rev. Agric. Econ. 38 (3) (2011) 427-447.

[13] IPCC, Climate Change 2007: Fourth Assessment Report of the Intergovernmental Panel on Climate Change. IPCC, Cambridge, United Kingdom/New York, NY, USA. 2007

[14] R. J. Troedson, D. E. L. Byth, and G. L. Milson, "Saturated soil culture and innovation water management option for soybean in the tropics and subtropics," in Soybean in Tropical and Subtropical Cropping System. Proceedings of the Symposium at Tsukuba, S. Shanmugasundaram and E. W. Sulzberger, Eds., 2003

[15] S. Y. Nugraha, T. Sumarni, E. Sulistyono. "Pengaruh interval waktu dan tingkat pemberian air terhadap pertumbuhan dan hasil kedelai (Glycine max (L.) Merril)". J. Produksi Tanaman 2 (2014) 552-559.
[16] Sharifa, A. Muriefah. "Effect of paclobutrazol on growth an physiological attributes of soybean (Glycine max) plants grown under water stress conditions”. Int. J. Adv. Res. Biol. Sci. 2 (2015) 8193.

[17] L. Taiz, E. Zeiger, Plant Physiology. Third Edition.Sinauer Associates, Massachusets: Inc. Publishers, 2002

[18] Aminah, Abdullah, Nuraeni, Marliana S.Palad, "Effectiveness of Water Management towards Soil Moisture Preservation on Soybeans". International Journal of Agronomi. 2020, DOI: https://doi.org/10.1155/2020/8653472

[19] T. Adisarwanto and R. Wudlanto, "Peningkatan hasil panen kedelai di lahan sawah kering-pasang Surut. Jakarta," Penebar Swadaya, vol. 33, pp. 1-3, 2007.

[20] Aminah, S. Jusoff, S. Hadijah et al., "Increasing soybean (Glycine max L) drought resistance with osmolit sorbitol," Modern Applied Science, vol. 7, no. 9, 2013. 